\title{
Stem Cutting Propagation in Whole Pine Tree Substrates
}

\author{
Anthony L. Witcher ${ }^{1,5,9}$, Eugene K. Blythe ${ }^{2,6}$, Glenn B. Fain ${ }^{3,7}$, \\ and Kenneth J. Curry ${ }^{4,8}$
}

ADDITIONAL INDEX WORDs. alternative substrate, growing media, peatmoss, pine bark, Pinus taeda

Summary. Wood-based substrates have been extensively evaluated for greenhouse and nursery crop production, yet these substrates have not been evaluated for propagation. The objective of this study was to evaluate processed whole loblolly pine trees (WPT) (Pinus taeda) as a rooting substrate for stem cutting propagation of a range of ornamental crops. Substrates included processed WPT, pine (Pinus sp.) bark (PB), and each mixed with equal parts (by volume) peatmoss (PM) (WPT:PM and PB:PM, respectively). Substrate physical (air space, container capacity, total porosity, bulk density, and particle size distribution) and chemical $[\mathrm{pH}$ and electrical conductivity (EC)] properties were determined for all substrates. Rooting percentage, total root length, total root volume, and total shoot length were evaluated for four species in 2008 and five species in 2009. Substrate air space was similar between PB and WPT in the 2008 experiment, and likewise between PB:PM and WPT:PM. In the 2009 experiment, PB and WPT had similar substrate air space. The addition of PM to PB and WPT resulted in reduced air space and increased container capacity in both experiments. The proportion of fine particles doubled for PB:PM and WPT:PM compared with PB and WPT, respectively.

Substrate $\mathrm{pH}$ for all substrates ranged from 6.0 to 6.9 at 7 days after sticking (DAS) cuttings and 6.9 to 7.1 at 79 DAS. Substrate EC was below the acceptable range for all substrates except at 7 DAS. Rooting percentage was similar among substrates within each species in both experiments. The addition of PM resulted in significantly greater total root length for PB:PM and WPT:PM compared with PB and WPT, respectively, for five of the eight species. Shoot growth was most vigorous for PB:PM compared with the other substrates for all species. The study demonstrated a range of plant species can be propagated from stem cuttings in whole pine tree substrates alone or combined with PM.

$\mathrm{C}$ utting propagation is the most widely used method for cloning nursery and floriculture crops. Some of the factors that affect successful cutting propagation include stock plant quality, timing of propagation, propagation environment,

We thank Donald Merhaut, Avery Christmas Tree Farm, and Yoder Brothers Inc. for providing cutting material, and to Dip 'N Grow Inc. for providing the auxin-containing product used in this study.

${ }^{1}$ USDA-ARS Thad Cochran Southern Horticultural Laboratory, 810 Hwy. 26 West, Poplarville, MS 39470

${ }^{2}$ Coastal Research and Extension Center, Mississippi State University, South Mississippi Branch Experiment Station, Poplarville, MS 39470

${ }^{3}$ Department of Horticulture, 101 Funchess Hall, Auburn University, AL 36849

${ }^{4}$ Department of Biological Sciences, University of Southern Mississippi, Johnson Science Tower 410, Hattiesburg, MS 39406

${ }^{5}$ Horticulturist

${ }^{6}$ Associate Research Professor

${ }^{7}$ Associate Professor

${ }^{8}$ Associate Professor

${ }^{9}$ Corresponding author. E-mail: anthony.witcher@ ars.usda.gov. container size, rooting substrate, and auxin treatment. A proper balance of air space and container capacity are critical for healthy root development, so the combined effects of propagation environment (mist application volume and frequency) and container size must be well understood when selecting a propagation substrate (Threadgill et al., 1985).

Sphagnum PM, PB, perlite, and vermiculite are commonly used as substrates for propagation, either individually or in combination at various proportions. The high transportation costs and variable annual harvest of Canadian PM have negatively impacted greenhouse crop producers in the United States (Fain et al., 2008; Harrison, 2011). Before the housing market decline of the late 2000s, nursery crop producers experienced a reduction in $\mathrm{PB}$ supplies and a rise in cost due to both PB's use as boiler fuel and a decline in the timber market (Lu et al., 2006). Although PB supplies have rebounded in recent years, the long-term availability of $\mathrm{PB}$ will remain a concern. Although many alternative substrates have been used to produce quality containergrown crops, it has not been determined if such substrates are suitable for propagation. Ideally, an alternative substrate component should be cost effective, sustainable, and regionally available.

Alternative substrates should be evaluated within a propagation environment before extensive use. Offord et al. (1998) demonstrated coconut coir was a suitable alternative to PM for propagation of sydney bush pea (Pultenaea parviflora). Shah et al. (2006) reported silt and sawdust as acceptable substrates for long-leaf fig (Ficus binnendijkii 'Amstel Queen') cutting propagation, yet a traditional substrate was not included for comparison. Composts derived from a variety of materials have also been used for cutting propagation. Cuttings of three foliage plant species had similar root development in composts mixed with $\mathrm{PM}$ or $\mathrm{PB}$ and in a standard substrate (Chen et al., 2003). Chong (1999) noted composted municipal waste blended with perlite was a satisfactory substrate for cutting propagation of several woody plant species.

Wood-based substrates have been identified as acceptable supplements

\begin{tabular}{llll}
\hline $\begin{array}{l}\text { Units } \\
\begin{array}{l}\text { To convert U.S. to SI, } \\
\text { multiply by }\end{array}\end{array}$ & U.S. unit & SI unit & $\begin{array}{l}\text { To convert SI to U.S., } \\
\text { multiply by }\end{array}$ \\
\hline 29.5735 & $\mathrm{fl} \mathrm{oz}$ & $\mathrm{mL}$ & 0.0338 \\
2.54 & inch(es) & $\mathrm{cm}$ & 0.3937 \\
25.4 & inch $(\mathrm{es})$ & $\mathrm{mm}$ & 0.0394 \\
16.3871 & inch & $\mathrm{cm}$ & 0.0610 \\
0.5933 & lb/yard & $\mathrm{kg} \cdot \mathrm{m}^{3}$ & 1.6856 \\
1 & $\mathrm{mmho} / \mathrm{cm}^{3}$ & $\mathrm{dS} \cdot \mathrm{m}^{-1}$ & 1 \\
1.7300 & $\mathrm{oz} / \mathrm{inch}^{3}$ & $\mathrm{~g} \cdot \mathrm{cm}^{-3}$ & 0.5780 \\
1 & $\mathrm{ppm}$ & $\mathrm{mg} \cdot \mathrm{L}^{-1}$ & 1 \\
0.7646 & yard & $\mathrm{m}$ & 1.3080 \\
$\left({ }^{\circ} \mathrm{F}-32\right) \div 1.8$ & ${ }^{\circ} \mathrm{F}$ & ${ }^{\circ} \mathrm{C}$ & $\left({ }^{\circ} \mathrm{C} \times 1.8\right)+32$
\end{tabular}


or replacements for $\mathrm{PM}$ and $\mathrm{PB}$ in crop production. Wood-based materials derived from pine trees are readily available throughout the southeastern United States and include clean chip residual (bark, limbs, and needles), processed whole pine trees (wood, bark, limbs, and needles), and chipped pine logs (wood and bark). These substrates have been extensively evaluated for greenhouse and nursery crop production (Boyer et al., 2008; Fain et al., 2008; Jackson et al., 2009; Wright and Browder, 2005). Although crops grown in these substrates commonly required additional fertilizer when compared with those grown in traditional substrates (Fain et al., 2008; Jackson et al., 2008; Wright et al., 2008), nutrient and water availability issues can be readily managed during crop production.

The suitability of loblolly pine wood-based substrates for cutting propagation has not been investigated. Demonstrating the versatility of these substrates is essential to expanding their commercial availability and use. The objective of the current experiments was to evaluate processed whole pine tree as a rooting substrate for stem cutting propagation of ornamental crops.

\section{Materials and methods}

Root development of stem cuttings in four substrates was evaluated in two experiments conducted in 2008 and 2009 at the U.S. Department of Agriculture Thad Cochran Southern Horticultural Laboratory in Poplarville, MS (lat. $30^{\circ} 50^{\prime} 12.6^{\prime \prime} \mathrm{N}$, long. $\left.89^{\circ} 32^{\prime} 45.3^{\prime \prime} \mathrm{W}\right)$. The substrates included processed WPT, PB, and each mixed with equal parts PM by volume to produce two additional substrates (WPT:PM and PB:PM). In the 2008 experiment, WPT was produced from 12-year-old loblolly pine trees harvested, then processed with a portable heavy-duty horizontal grinder with 4 -inch screens (Peterson 4700B; Peterson Pacific Corp., Eugene, OR) in Jan. 2007 and the resulting material was stored outside in full sun. In Apr. 2007, the material was further processed through a hammer mill (No. 30; C.S. Bell, Tiffin, $\mathrm{OH})$ fitted with a $3 / 16$-inch screen and stored in 2.4-yard ${ }^{3}$ polypropylene bulk bags placed under a canopy. In the 2009 experiment, WPT was produced from 7.8- to 9.8-inch (diameter

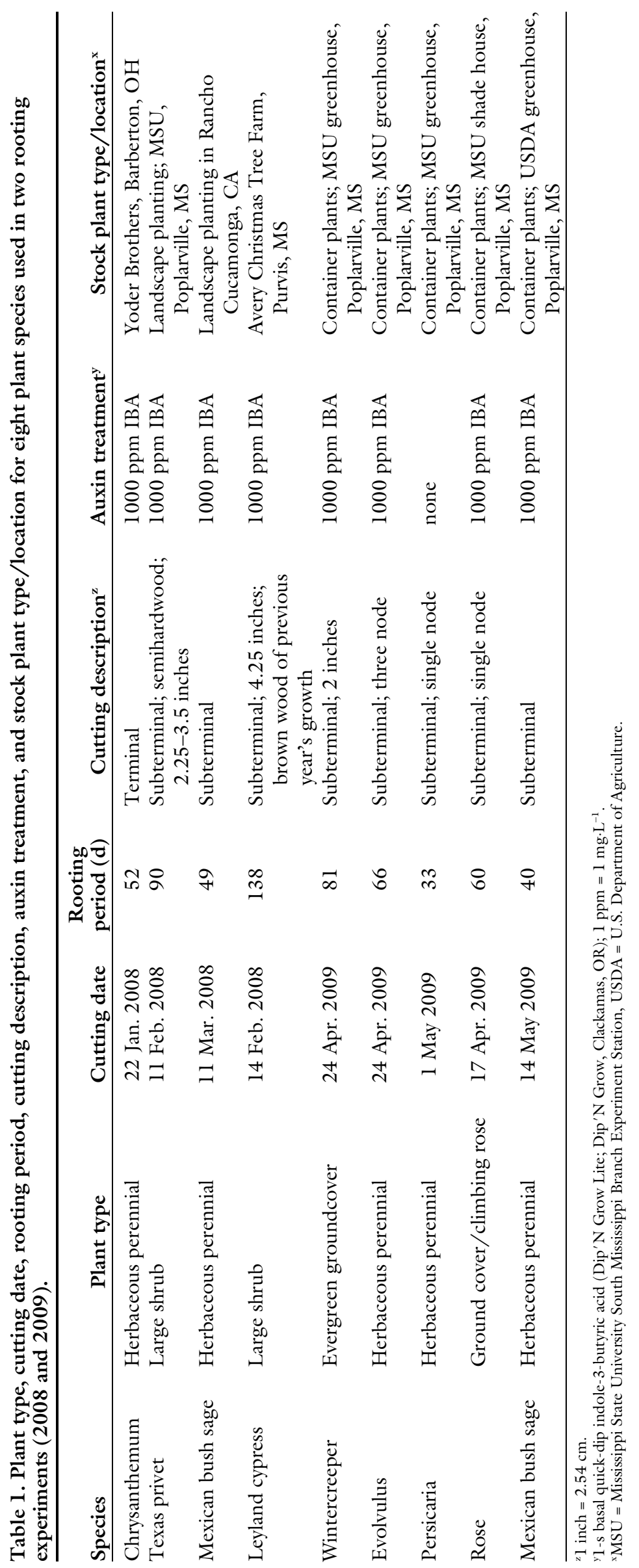


at breast height) loblolly pine trees harvested in Macon County, AL, and chipped (model 334 Biomass Chipper; Woodsman, Farwell, MI) on 19 Jan. 2009. Chips were ground with a hammer mill (Meteor Mill \#40; Williams Patent Crusher and Pulverizer Co., St. Louis, MO) to pass a $3 / 8$-inch screen. A small-scale hammer mill was used to process WPT in the 2008 experiment, but the authors had access to an industrial-scale hammer mill to process WPT in the 2009 experiment. Although the industrial hammer mill was fitted with a larger screen size, the higher velocity and greater capacity resulted in a material with physical properties comparable to material processed with a smaller hammer mill and screen size.

In both experiments, each substrate was amended with $4 \mathrm{lb} /$ yard $^{3}$ $16 \mathrm{~N}-2.6 \mathrm{P}-10 \mathrm{~K}$ (5-month formulation plus micronutrients; Harrell's, Sylacauga, AL) and $5 \mathrm{lb} /$ yard $^{3}$ dolomitic limestone. Individual $6.6-\mathrm{cm}^{2}$ (232 $\mathrm{mL}$ volume) plastic containers (SVD-250; T.O. Plastics, Clearwater, $\mathrm{MN}$ ) were filled with substrate, completely randomized in six carry trays (SPT-250-32-PF, T.O. Plastics), and placed under a greenhouse mist system 24 to $48 \mathrm{~h}$ before use to thoroughly moisten substrates.

The plant species used in the two experiments were chosen based on accessibility and to represent a range of plant types and rooting difficulty. In the 2008 experiment, species used were chrysanthemum (Chrysanthemum $\times$ morifolium 'Dazzling Stacy'), leyland cypress [Cupressus $\times$ leylandii (synonym $\times$ Cupressocyparis leylandii) 'Murray'], texas privet (Ligustrum japonicum 'Texanum'), and mexican bush sage (Salvia leucantha). In the 2009 experiment, species used were wintercreeper (Euonymus fortunei 'Kewensis'), evolvulus (Evolvulus glomeratus 'Blue Daze'), persicaria [Polygonum microcephalum (synonym Persicaria microcephala) 'Red Dragon'], rose (Rosa 'Red Cascade'), and mexican bush sage (Salvia leucantha).

Stem cuttings from individual plant species were prepared (Table 1), all species (except persicaria) received a 1 -s basal quick-dip in a $1000 \mathrm{ppm}$ indole-3-butyric acid solution (Dip' $\mathrm{N}$ Grow Lite; Dip' N Grow, Clackamas, OR), and a single cutting was inserted into each container for a total of 192 experimental units per species. Intermittent mist was maintained for all species at $8 \mathrm{~s}$ every $15 \mathrm{~min}$ from 8:00 AM to 6:00 PM (2008 experiment) and at $5 \mathrm{~s}$ every $15 \mathrm{~min}$ from 7:00 AM to 6:00 PM (2009 experiment). Pin-Perfect nozzles (Dramm Corp., Manitowoc, WI) were used in the 2008 experiment and mister nozzles (809 Series; Ein-Dor Co., Yavne, Israel) were used in the 2009 experiment. In the 2008 experiment, average monthly greenhouse temperature was $20^{\circ} \mathrm{C}$ (February), $20^{\circ} \mathrm{C}$ (March), $20^{\circ} \mathrm{C}$ (April), $22^{\circ} \mathrm{C}$ (May), and $25^{\circ} \mathrm{C}$ (June). In the 2009 experiment, average monthly greenhouse temperature was $22^{\circ} \mathrm{C}$ (April), $22^{\circ} \mathrm{C}$ (May), $24^{\circ} \mathrm{C}$ (June), and $27^{\circ} \mathrm{C}$ (July). Day length ranged from 11 to $13.8 \mathrm{~h}$ in 2008 and 13 to $14.1 \mathrm{~h}$ in 2009 .

Rooting periods varied by species, but all cuttings within a species were harvested at the same time (Table 1). Upon harvest, roots (if present) were washed and digitally scanned for analysis (total root length and total root volume) using WinRhizo software (version 2007d; Regent Instruments, Sainte-Foy, QC, Canada). New shoot growth (if present) was recorded as total shoot length. In the 2009 experiment, substrate solution was extracted from fallow containers $(n=4)$ at $7,29,52$, and 79 DAS the cuttings via the pour-through method (Wright, 1986). Substrate solution $\mathrm{pH}$ and EC were analyzed using a multiparameter meter (Accumet Excel

Table 2. Physical properties of pine bark and whole pine tree substrates in a 2008 cutting propagation experiment. ${ }^{\mathrm{z}}$

\begin{tabular}{lcccr}
\hline Substrate & $\begin{array}{c}\text { Air space } \\
(\% \mathbf{~ v o l})\end{array}$ & $\begin{array}{c}\text { Container } \\
\text { capacity } \\
(\% \text { vol })\end{array}$ & $\begin{array}{c}\text { Total } \\
\text { porosity } \\
(\% \text { vol })\end{array}$ & $\begin{array}{r}\text { Bulk } \\
\text { density } \\
\left(\mathbf{g}^{\circ} \mathbf{c m}^{-3}\right)^{\mathbf{y}}\end{array}$ \\
\hline Pine bark & $35.5 \mathrm{a}^{\mathrm{x}}$ & $52.0 \mathrm{~b}$ & $87.3 \mathrm{a}$ & $0.292 \mathrm{a}$ \\
1 Pine bark:1 peatmoss & $16.3 \mathrm{~b}$ & $66.6 \mathrm{a}$ & $82.9 \mathrm{~b}$ & $0.264 \mathrm{~b}$ \\
Whole pine tree $^{\mathrm{w}}$ & $31.0 \mathrm{a}$ & $51.7 \mathrm{~b}$ & $82.7 \mathrm{~b}$ & $0.184 \mathrm{c}$ \\
1 Whole pine tree:1 peatmoss & $16.5 \mathrm{~b}$ & $64.8 \mathrm{a}$ & $81.3 \mathrm{~b}$ & $0.219 \mathrm{~d}$ \\
Pine bark vs. whole pine tree $^{\mathrm{v}}$ & 0.1067 & 0.214 & 0.0168 & $<0.0001$ \\
Peat vs. none $^{\mathrm{u}}$ & $<0.0001$ & $<0.0001$ & 0.0238 & 0.6703 \\
\hline
\end{tabular}

${ }^{2}$ Data presented as means $(n=3)$ and obtained using the North Carolina State University porometer method (Fonteno et al., 1995).

${ }^{\mathrm{y}} \mathrm{g} \cdot \mathrm{cm}^{-3}=0.5780 \mathrm{oz} / \mathrm{inch}^{3}$

xMeans followed by different letters within columns indicate significant difference at $P<0.05$ using the Shaffersimulated method.

" 12 -year-old whole loblolly pine trees harvested, chipped, and hammermilled to pass a $0.47-\mathrm{cm} s \mathrm{sreen} ; \mathrm{l} \mathrm{cm}=$ 0.3937 inch.

'Tested differences between substrates containing pine bark and substrates containing whole pine tree; $P<0.05$. "Tested differences between substrates amended with peatmoss (peat) and substrates with no peatmoss (none); $P<$ 0.05

Table 3. Physical properties of pine bark and whole pine tree substrates in a 2009 cutting propagation experiment. ${ }^{\mathrm{z}}$

\begin{tabular}{|c|c|c|c|c|}
\hline Substrate & $\begin{array}{c}\text { Air space } \\
\text { (\% vol) }\end{array}$ & $\begin{array}{c}\text { Container } \\
\text { capacity } \\
(\% \text { vol })\end{array}$ & $\begin{array}{c}\text { Total } \\
\text { porosity } \\
(\% \text { vol })\end{array}$ & $\begin{array}{c}\text { Bulk } \\
\text { density } \\
\left(\mathrm{g} \cdot \mathrm{cm}^{-3}\right)^{y}\end{array}$ \\
\hline Pine bark & $24.0 b^{x}$ & $53.9 \mathrm{~b}$ & $77.9 \mathrm{~b}$ & $0.312 \mathrm{a}$ \\
\hline 1 Pine bark: 1 peatmoss & $17.7 \mathrm{c}$ & $58.0 \mathrm{ab}$ & $75.7 \mathrm{~b}$ & $0.248 \mathrm{~b}$ \\
\hline Whole pine tree $\mathrm{e}^{\mathrm{w}}$ & $31.7 \mathrm{a}$ & $55.5 \mathrm{~b}$ & $87.1 \mathrm{a}$ & $0.163 \mathrm{c}$ \\
\hline 1 Whole pine tree: 1 peatmoss & $22.6 \mathrm{~b}$ & $60.5 \mathrm{a}$ & $83.1 \mathrm{a}$ & $0.190 \mathrm{~d}$ \\
\hline Pine bark vs. whole pine tree ${ }^{\mathrm{v}}$ & $<0.0001$ & 0.1437 & $<0.0001$ & $<0.0001$ \\
\hline Peat vs. none $\mathrm{u}^{\mathrm{u}}$ & $<0.0001$ & 0.006 & 0.0182 & 0.0235 \\
\hline
\end{tabular}

${ }^{2}$ Data presented as means $(n=3)$ and obtained using the North Carolina State University porometer method (Fonteno et al., 1995).

${ }^{\mathrm{y}} 1 \mathrm{~g} \cdot \mathrm{cm}^{-3}=0.5780 \mathrm{oz} / \mathrm{inch}^{3}$

${ }^{x}$ Means followed by different letters within columns indicate significant difference at $P<0.05$ using the Shaffersimulated method.

w20- to $25-\mathrm{cm}$ diameter whole loblolly pine trees harvested, chipped, and hammermilled to pass a 0.95 -cm screen; $1 \mathrm{~cm}=0.3937$ inch.

vTested differences between substrates containing pine bark and substrates containing whole pine tree; $P<0.05$. uTested differences between substrates amended with peatmoss (peat) and substrates with no peatmoss (none); $P<$ 0.05 . 
XL50; Fisher Scientific, Pittsburgh, PA). Substrate air space, container capacity, total porosity, and bulk density were determined $(n=3)$ using the North Carolina State University porometer method (Fonteno et al., 1995). Substrate particle size distribution (PSD) was determined by passing 500-mL air-dried substrate samples $(n=3)$ through 11 sieves (9.5 to $0.05 \mathrm{~mm}$ ). Sieves were shaken for 3 min with a sieve shaker [278 oscillations/min, 159 taps/min (RoTap RX-29; W.S. Tyler, Mentor, $\mathrm{OH})$ ]. Particles collected on each sieve and in the pan $(<0.05 \mathrm{~mm})$ were weighed and grouped into three texture classes [coarse $(>2.0 \mathrm{~mm})$, medium $(2.0$ to $0.5 \mathrm{~mm})$, and fine $(<0.5 \mathrm{~mm})]$.

Assumptions of normality and common variance were tested (except for rooting percentage) using the GLM and UNIVARIATE procedures of SAS (version 9.3; SAS Institute, Cary, NC). Rooting percentage data were analyzed using the MULTTEST procedure of SAS, with differences between treatment means determined using Fisher's exact test with a permutation adjustment for multiple comparisons $(P<0.05)$. Total root length, total root volume, total shoot length, porometer data, PSD data, $\mathrm{pH}$, and $\mathrm{EC}$ were analyzed with linear models using the GLIMMIX procedure of SAS. Differences between treatment means were determined using the Shaffer-Simulated method $(P<0.05)$. Linear contrasts were used to test differences between means for PM-amended substrates (included PB:PM and WPT:PM) and the non-PM-amended substrates (included PB and WPT), and differences between means for whole pine tree substrates (included WPT and WPT:PM) and $\mathrm{PB}$ substrates (included $\mathrm{PB}$ and $\mathrm{PB}: \mathrm{PM})$.

\section{Results and discussion}

Substrate air space ranged from $16.3 \%(\mathrm{~PB}: \mathrm{PM})$ to $35.5 \%(\mathrm{~PB})$ in the 2008 experiment (Table 2), and from $17.7 \%$ (PB:PM) to $31.7 \%$ (WPT) in the 2009 experiment (Table 3). Substrate air space was similar between $\mathrm{PB}$ and WPT in the 2008 experiment, and likewise between PB:PM and WPT:PM. In the 2009 experiment, PB and WPT had similar substrate air space. Substrate container capacity ranged from 51.8\% to $66.6 \%$ (2008 experiment) and $53.9 \%$ to $60.5 \%$ (2009 experiment).
The addition of PM to $\mathrm{PB}$ and WPT resulted in reduced air space and increased container capacity in both experiments. Substrate air space was significantly lower in $\mathrm{PB}: \mathrm{PM}$ and WPT:PM compared with $\mathrm{PB}$ and WPT, respectively, in both experiments. In the 2008 experiment,

Table 4. Particle size distribution (PSD) of pine bark and whole pine tree substrates in a 2008 cutting propagation experiment. ${ }^{\mathrm{z}}$

\begin{tabular}{|c|c|c|c|c|}
\hline \multirow[b]{3}{*}{ Sieve opening $(\mathrm{mm})^{\mathrm{y}}$} & \multicolumn{4}{|c|}{ Substrate } \\
\hline & Pine bark & $\begin{array}{l}1 \text { Pine bark:1 } \\
\text { peatmoss (v:v) }\end{array}$ & $\begin{array}{l}\text { Whole } \\
\text { pine tree }^{x}\end{array}$ & $\begin{array}{c}\text { 1 Whole } \\
\text { pine tree: } 1 \\
\text { peatmoss (v:v) }\end{array}$ \\
\hline & \multicolumn{4}{|c|}{$\begin{array}{c}\text { PSD (\%) } \\
\end{array}$} \\
\hline 6.3 & 10.1 & 6.1 & 0.1 & 0.0 \\
\hline 3.4 & 29.7 & 15.4 & 8.6 & 5.4 \\
\hline 2.4 & 17.3 & 9.4 & 21.4 & 13.0 \\
\hline 2.0 & 6.6 & 3.9 & 10.2 & 6.0 \\
\hline 1.4 & 11.3 & 10.0 & 16.3 & 10.7 \\
\hline 1.0 & 6.1 & 9.1 & 10.3 & 8.0 \\
\hline 0.5 & 7.3 & 18.3 & 13.3 & 16.0 \\
\hline 0.25 & 7.3 & 17.1 & 9.9 & 16.0 \\
\hline 0.106 & 3.0 & 7.9 & 7.5 & 17.2 \\
\hline 0.053 & 0.6 & 1.9 & 1.8 & 5.9 \\
\hline Pan & 0.6 & 0.9 & 0.6 & 1.7 \\
\hline \multicolumn{5}{|l|}{ Texture class ${ }^{w}$} \\
\hline Coarse & $63.8 \mathrm{a}^{\mathrm{v}}$ & $34.9 \mathrm{c}$ & $40.2 \mathrm{~b}$ & $24.4 \mathrm{~d}$ \\
\hline Medium & $24.8 \mathrm{~d}$ & $37.4 \mathrm{~b}$ & $40.0 \mathrm{a}$ & $34.8 \mathrm{c}$ \\
\hline Fine & $11.5 \mathrm{~d}$ & $27.8 \mathrm{~b}$ & $19.8 \mathrm{c}$ & $40.9 \mathrm{a}$ \\
\hline
\end{tabular}

${ }^{2}$ Data presented as means $(n=3)$ of percent of particles collected on sieves and in pan.

${ }^{\mathrm{y}} \mathrm{l} \mathrm{mm}=0.0394$ inch.

${ }^{x} 12$-year-old whole loblolly pine trees harvested, chipped, and hammermilled to pass a $0.47-\mathrm{cm}$ screen; $1 \mathrm{~cm}=$ 0.3937 inch.

wTexture classes: coarse $(>2.0 \mathrm{~mm})$, medium $(2.0-0.5 \mathrm{~mm})$, and fine $(<0.5 \mathrm{~mm})$.

${ }^{v}$ Means followed by different letters within rows indicate significant difference at $P<0.05$ using the Shaffersimulated method.

Table 5. Particle size distribution (PSD) of pine bark and whole pine tree substrates in a 2009 cutting propagation experiment. ${ }^{2}$

\begin{tabular}{|c|c|c|c|c|}
\hline \multirow[b]{3}{*}{ Sieve opening $(\mathrm{mm})^{\mathrm{y}}$} & \multicolumn{4}{|c|}{ Substrate } \\
\hline & Pine bark & $\begin{array}{l}\text { I Pine bark:1 } \\
\text { peatmoss (v:v) }\end{array}$ & $\begin{array}{l}\text { Whole } \\
\text { pine tree }^{\mathrm{x}}\end{array}$ & $\begin{array}{l}1 \text { Whole pine tree: } 1 \\
\text { peatmoss (v:v) }\end{array}$ \\
\hline & \multicolumn{4}{|c|}{ PSD (\%) } \\
\hline 6.3 & 20.4 & 16.7 & 0.0 & 2.2 \\
\hline 3.4 & 17.9 & 15.1 & 1.7 & 5.2 \\
\hline 2.4 & 10.1 & 7.7 & 9.1 & 7.0 \\
\hline 2.0 & 3.8 & 2.7 & 8.8 & 5.1 \\
\hline 1.4 & 9.9 & 7.6 & 24.4 & 15.3 \\
\hline 1.0 & 8.1 & 6.6 & 17.7 & 11.5 \\
\hline 0.5 & 14.3 & 14.5 & 21.1 & 18.5 \\
\hline 0.25 & 8.6 & 12.9 & 11.3 & 15.9 \\
\hline 0.106 & 4.6 & 11.3 & 4.9 & 14.0 \\
\hline 0.053 & 1.4 & 3.5 & 0.8 & 4.1 \\
\hline Pan & 0.9 & 1.5 & 0.2 & 1.3 \\
\hline \multicolumn{5}{|l|}{ Texture class ${ }^{\mathrm{w}}$} \\
\hline Coarse & $52.2 \mathrm{a}^{\mathrm{v}}$ & $42.1 \mathrm{~b}$ & $19.6 \mathrm{c}$ & $19.5 \mathrm{c}$ \\
\hline Medium & $32.2 \mathrm{c}$ & $28.7 \mathrm{~d}$ & $63.2 \mathrm{a}$ & $45.3 \mathrm{~b}$ \\
\hline Fine & $15.5 \mathrm{~d}$ & $29.2 \mathrm{~b}$ & $17.2 \mathrm{c}$ & $35.2 \mathrm{a}$ \\
\hline
\end{tabular}

${ }^{z}$ Data presented as means $(n=3)$ of percent of particles collected on sieves and in pan.

$\mathrm{y} 1 \mathrm{~mm}=0.0394$ inch

20 - to $25-\mathrm{cm}$ diameter whole loblolly pine trees harvested, chipped, and hammermilled to pass a 0.95 - $\mathrm{cm}$ screen; 1 $\mathrm{cm}=0.3937$ inch.

wTexture classes: coarse $(>2.0 \mathrm{~mm})$, medium $(2.0-0.5 \mathrm{~mm})$, and fine $(<0.5 \mathrm{~mm})$.

${ }^{v}$ Means followed by different letters within rows indicate significant difference at $P<0.05$ using the Shaffersimulated method. 
substrate container capacity was significantly greater in PB:PM and WPT:PM compared with PB and WPT, respectively. Total porosity was greatest in $\mathrm{PB}$ compared with the other substrates in the $2008 \mathrm{ex}^{-}$ periment, but similar between $\mathrm{PB}$ and PB:PM and between WPT and WPT:PM in the 2009 experiment. Bulk density decreased with the addition of PM to PB, but increased with the addition of PM to WPT in both experiments. Peatmoss has high water retention properties and is routinely used to enhance the container capacity of substrates used for crop production (Robbins and Evans, 2005).

Substrate air space between $15 \%$ and $40 \%$ is recommended for adequate aeration during propagation, whereas substrate container capacity between $20 \%$ and $60 \%$ is recommended for adequate water retention. Also, 0.3 to $0.8 \mathrm{~g} \cdot \mathrm{cm}^{-3}$ bulk density is recommended for propagation substrates (Hartmann et al., 2002; Threadgill et al., 1985). Substrate air space was within the recommended range for substrates used in both experiments, whereas substrate container capacity was slightly greater than the recommended range for PB:PM and WPT:PM in the 2008 experiment.

Pine bark substrate had the lowest proportion of fine particles followed by WPT, PB:PM, and WPT:PM in both experiments (Tables 4 and 5 ). The proportion of fine particles doubled for PB:PM and WPT:PM compared with $\mathrm{PB}$ and $\mathrm{WPT}$, respectively. It has been reported that substrate particles less than $0.5 \mathrm{~mm}$ can have a significant effect on substrate air space and container capacity (Jackson et al., 2010; Owen and Altland, 2008). The greater proportion of fine particles most likely resulted in the greater substrate container capacity and lower substrate air space of the substrates amended with PM.

Rooting percentage was similar among substrates within each species in both experiments (Table 6). Rooting percentage was $90 \%$ or greater for all species except texas privet. The high rooting success is an indication that substrate did not have a significant effect on root initiation or rooting percentage in either experiment. Root development response to substrate varied by species in both experiments. Root development in WPT was less vigorous compared with the other substrates, yet the differences were not always significant. Total root length (Table 7 ) and total root volume

Table 6. Mean rooting percentage of cuttings from eight species rooted in pine bark and whole pine tree substrates.

\begin{tabular}{|c|c|c|c|c|}
\hline \multirow[b]{3}{*}{ Species } & \multicolumn{4}{|c|}{ Substrate } \\
\hline & Pine bark & $\begin{array}{l}1 \text { Pine bark:1 } \\
\text { peatmoss (v:v) }\end{array}$ & $\begin{array}{c}\text { Whole } \\
\text { pine tree }^{z}\end{array}$ & $\begin{array}{l}1 \text { Whole pine tree: } 1 \\
\text { peatmoss (v:v) }\end{array}$ \\
\hline & \multicolumn{4}{|c|}{ Rooting (\%) } \\
\hline \multicolumn{5}{|l|}{2008 experiment } \\
\hline Chrysanthemum & $100 a^{y}$ & $100 \mathrm{a}$ & $100 \mathrm{a}$ & $100 \mathrm{a}$ \\
\hline Leyland cypress & $94 \mathrm{a}$ & $96 a$ & $90 \mathrm{a}$ & $96 a$ \\
\hline Texas privet & $88 \mathrm{a}$ & $83 \mathrm{a}$ & $75 \mathrm{a}$ & $75 \mathrm{a}$ \\
\hline Mexican bush sage & $100 \mathrm{a}$ & $100 \mathrm{a}$ & $100 \mathrm{a}$ & $100 \mathrm{a}$ \\
\hline \multicolumn{5}{|l|}{2009 experiment } \\
\hline Wintercreeper & $100 \mathrm{a}$ & $100 \mathrm{a}$ & $100 \mathrm{a}$ & $100 \mathrm{a}$ \\
\hline Evolvulus & $100 \mathrm{a}$ & $100 \mathrm{a}$ & $94 \mathrm{a}$ & $94 \mathrm{a}$ \\
\hline Persicaria & $100 \mathrm{a}$ & $100 \mathrm{a}$ & $100 \mathrm{a}$ & $100 \mathrm{a}$ \\
\hline Rose & $94 \mathrm{a}$ & $98 \mathrm{a}$ & $94 \mathrm{a}$ & $100 \mathrm{a}$ \\
\hline Mexican bush sage & $100 \mathrm{a}$ & $100 \mathrm{a}$ & $100 \mathrm{a}$ & $100 \mathrm{a}$ \\
\hline
\end{tabular}

Table 7. Mean total root length of cuttings from eight species rooted in pine bark and whole pine tree substrates.

\begin{tabular}{|c|c|c|c|c|c|c|}
\hline \multirow[b]{3}{*}{ Species } & \multicolumn{4}{|c|}{ Substrate } & \multirow{3}{*}{$\begin{array}{l}\text { Pine bark vs. whole } \\
\text { pine tree }\end{array}$} & \multirow[b]{3}{*}{ Peat vs. none } \\
\hline & $\underline{\text { Pine bark }}$ & $\begin{array}{c}1 \text { Pine bark: } 1 \\
\text { peatmoss (v:v) }\end{array}$ & $\begin{array}{c}\text { Whole pine } \\
\text { tree }^{\mathrm{z}}\end{array}$ & $\begin{array}{c}1 \text { Whole pine tree: } \\
1 \text { peatmoss (v:v) }\end{array}$ & & \\
\hline & \multicolumn{4}{|c|}{ Total root length $(\mathrm{cm})$} & & \\
\hline \multicolumn{7}{|l|}{2008 experiment } \\
\hline Chrysanthemum & $1353 b^{w}$ & $1481 \mathrm{a}$ & $1046 \mathrm{c}$ & $1051 \mathrm{c}$ & $<0.0001$ & 0.0635 \\
\hline Leyland cypress & 570 a & $379 \mathrm{~b}$ & $249 \mathrm{c}$ & $295 \mathrm{c}$ & $<0.0001$ & 0.0144 \\
\hline \multicolumn{7}{|l|}{2009 experiment } \\
\hline Wintercreeper & $165 \mathrm{~b}$ & $226 \mathrm{a}$ & $111 \mathrm{c}$ & $165 \mathrm{~b}$ & $<0.0001$ & $<0.0001$ \\
\hline Evolvulus & $752 \mathrm{~b}$ & $1173 \mathrm{a}$ & $462 \mathrm{c}$ & $907 \mathrm{~b}$ & $<0.0001$ & $<0.0001$ \\
\hline Persicaria & $1055 \mathrm{~b}$ & 1469 a & $916 \mathrm{~b}$ & 1431 a & 0.0608 & $<0.0001$ \\
\hline Rose & $236 \mathrm{c}$ & 647 a & $91 \mathrm{~d}$ & 398 b & $<0.0001$ & $<0.0001$ \\
\hline
\end{tabular}


(Table 8) were similar in WPT and PB for persicaria, whereas total root length was similar among all substrates for mexican bush sage in the 2009 experiment. Total root length and total root volume was similar between PB and WPT:PM for wintercreeper and evolvulus. Maximum total root length was observed in PB:PM for all species except leyland cypress and mexican bush sage (2009 experiment). In most cases, results for total root length mirrored the results for total root volume within a species.
The addition of PM resulted in significantly greater total root length for PB:PM compared with $\mathrm{PB}$ for chrysanthemum, wintercreeper, evolvulus, persicaria, and rose. The increased total root length between PB and $\mathrm{PB}: \mathrm{PM}$ ranged from 9\% (chrysanthemum) to $174 \%$ (rose). Similarly, significantly greater total root length in WPT:PM compared with WPT occurred for mexican bush sage (2008 experiment), wintercreeper, evolvulus, persicaria, and rose. The increase in total root length using
WPT:PM compared with WPT ranged from 26\% (mexican bush sage-2008 experiment) to $337 \%$ (rose).

Shoot growth was most vigorous for PB:PM compared with the other substrates for all species (Table 9). A positive response for total shoot length was observed in PB:PM and WPT:PM, compared with $\mathrm{PB}$ and WPT, respectively.

Peatmoss has a greater waterholding capacity and lower aeration compared with PB and wood-based substrates (Raviv and Lieth, 2008).

Table 8. Mean total root volume of cuttings from eight species rooted in pine bark and whole pine tree substrates.

\begin{tabular}{|c|c|c|c|c|c|c|}
\hline \multirow[b]{3}{*}{ Species } & \multicolumn{4}{|c|}{ Substrate } & \multirow{3}{*}{$\begin{array}{c}\text { Pine bark vs. } \\
\text { whole pine tree }\end{array}$} & \multirow[b]{3}{*}{ Peat vs. none ${ }^{x}$} \\
\hline & Pine bark & $\begin{array}{c}1 \text { Pine bark: } 1 \\
\text { peatmoss (v:v) }\end{array}$ & $\begin{array}{c}\text { Whole pine } \\
\text { tree }^{\mathrm{z}}\end{array}$ & $\begin{array}{l}\text { 1 Whole pine tree: } \\
1 \text { peatmoss (v:v) }\end{array}$ & & \\
\hline & \multicolumn{4}{|c|}{ Total root vol $\left(\mathrm{cm}^{3}\right)^{\mathrm{w}}$} & & \\
\hline \multicolumn{7}{|l|}{2008 experiment } \\
\hline Chrysanthemum & $2.16 \mathrm{a}^{\mathrm{v}}$ & $2.36 \mathrm{a}$ & $1.81 \mathrm{~b}$ & $1.9 \mathrm{~b}$ & $<0.0001$ & 0.0411 \\
\hline Leyland cypress & $1.75 \mathrm{a}$ & $1.20 \mathrm{~b}$ & $0.79 \mathrm{c}$ & $0.94 \mathrm{c}$ & $<0.0001$ & 0.025 \\
\hline \multicolumn{7}{|l|}{2009 experiment } \\
\hline Wintercreeper & $0.21 \mathrm{~b}$ & $0.28 \mathrm{a}$ & $0.15 \mathrm{c}$ & $0.22 \mathrm{~b}$ & $<0.0001$ & $<0.0001$ \\
\hline Evolvulus & $1.12 \mathrm{~b}$ & $1.80 \mathrm{a}$ & $0.69 \mathrm{c}$ & $1.35 \mathrm{~b}$ & 0.0003 & $<0.0001$ \\
\hline Persicaria & $0.56 \mathrm{~b}$ & $0.85 \mathrm{a}$ & $0.53 \mathrm{~b}$ & $0.96 \mathrm{a}$ & 0.3499 & $<0.0001$ \\
\hline Rose & $0.31 \mathrm{c}$ & $0.84 \mathrm{a}$ & $0.15 \mathrm{~d}$ & $0.54 \mathrm{~b}$ & $<0.0001$ & $<0.0001$ \\
\hline
\end{tabular}

Table 9. Mean total shoot length of cuttings from eight species rooted in pine bark and whole pine tree substrates.

\begin{tabular}{|c|c|c|c|c|c|c|}
\hline \multirow[b]{3}{*}{ Species } & \multicolumn{4}{|c|}{ Substrate } & \multirow{3}{*}{$\begin{array}{l}\text { Pine bark vs. } \\
\text { whole pine tree }\end{array}$} & \multirow[b]{3}{*}{ Peat vs. none ${ }^{\mathrm{x}}$} \\
\hline & Pine bark & $\begin{array}{l}\text { l Pine bark:l } \\
\text { peatmoss (v:v) }\end{array}$ & Whole pine tree ${ }^{\mathrm{z}}$ & $\begin{array}{l}\text { 1 Whole pine tree: } \\
1 \text { peatmoss (v:v) }\end{array}$ & & \\
\hline & \multicolumn{4}{|c|}{ Total shoot length $(\mathrm{cm})$} & & \\
\hline \multicolumn{7}{|l|}{2008 experiment } \\
\hline Chrysanthemum & NA & NA & NA & NA & NA & NA \\
\hline Leyland cypress & NA & NA & NA & NA & NA & NA \\
\hline \multicolumn{7}{|l|}{2009 experiment } \\
\hline Wintercreeper & NA & NA & NA & NA & NA & NA \\
\hline Evolvulus & $18.3 \mathrm{~b}$ & $30.0 \mathrm{a}$ & $10.5 \mathrm{c}$ & $26.6 \mathrm{a}$ & 0.0016 & $<0.0001$ \\
\hline Persicaria & $16.9 \mathrm{~b}$ & $31.0 \mathrm{a}$ & $13.2 \mathrm{~b}$ & $26.3 \mathrm{a}$ & 0.01 & $<0.0001$ \\
\hline Rose & $6.0 \mathrm{~b}$ & $11.7 \mathrm{a}$ & $3.3 \mathrm{~b}$ & $7.0 \mathrm{~b}$ & 0.0024 & 0.0001 \\
\hline
\end{tabular}

${ }^{\mathrm{z}} 12$-year-old whole loblolly pine trees harvested, chipped, and hammermilled to pass a 0.47 -cm screen (2008 experiment); 20 - to 25 -cm diameter whole loblolly pine trees harvested, chipped, and hammermilled to pass a $0.95-\mathrm{cm}$ screen $(2009$ experiment $) ; 1 \mathrm{~cm}=0.3937$ inch.

${ }^{y}$ Probability values for tests of differences between substrates containing pine bark and substrates containing whole pine tree.

'Probability values for tests of differences between substrates amended with peatmoss (peat) and substrates with no peatmoss (none).

wMeans followed by different letters within rows indicate significant difference at $P<0.05$ using the Shaffer-simulated method. 
Table 10. Substrate $\mathrm{pH}$ and electrical conductivity (EC) of pine bark and whole pine tree substrates in fallow containers at 7 , 29, 52, and $79 \mathrm{~d}$ after sticking cuttings (DAS) in a 2009 cutting propagation experiment.

\begin{tabular}{|c|c|c|c|c|c|c|c|c|}
\hline \multirow[b]{2}{*}{ Substrate } & \multicolumn{2}{|r|}{7 DAS } & \multicolumn{2}{|c|}{29 DAS } & \multicolumn{2}{|c|}{52 DAS } & \multicolumn{2}{|r|}{79 DAS } \\
\hline & $\mathrm{pH}$ & $\mathrm{EC}\left(\mathrm{dS} \cdot \mathrm{m}^{-1}\right)^{\mathrm{z}}$ & $\mathrm{pH}$ & $\mathrm{EC}\left(\mathrm{dS} \cdot \mathrm{m}^{-1}\right)$ & $\mathrm{pH}$ & $\mathrm{EC}\left(\mathrm{dS} \cdot \mathrm{m}^{-1}\right)$ & $\mathrm{pH}$ & $\mathrm{EC}\left(\mathrm{dS} \cdot \mathrm{m}^{-1}\right)$ \\
\hline Pine bark & $6.9 \mathrm{a}^{\mathrm{y}}$ & $0.47 \mathrm{a}$ & $7.2 \mathrm{a}$ & $0.19 \mathrm{a}$ & $7.1 \mathrm{a}$ & $0.21 \mathrm{a}$ & $7.1 \mathrm{a}$ & $0.15 \mathrm{ab}$ \\
\hline Whole pine tree $e^{x}$ & $6.4 \mathrm{~b}$ & $0.91 \mathrm{a}$ & $7.2 \mathrm{a}$ & $0.18 \mathrm{a}$ & $7.1 \mathrm{a}$ & $0.23 \mathrm{a}$ & $7.0 \mathrm{a}$ & $0.17 \mathrm{a}$ \\
\hline 1 Whole pine tree: 1 peatmoss & $6.0 \mathrm{c}$ & $0.84 \mathrm{a}$ & $7.0 \mathrm{~b}$ & $0.16 \mathrm{a}$ & $6.7 \mathrm{~b}$ & $0.18 \mathrm{a}$ & $6.9 \mathrm{a}$ & $0.13 \mathrm{~b}$ \\
\hline
\end{tabular}

${ }^{\mathrm{z}} \mathrm{l} \mathrm{dS} \cdot \mathrm{m}^{-1}=1 \mathrm{mmho} / \mathrm{cm}$.

${ }^{y}$ Means followed by different letters within columns indicate significant difference at $P<0.05(n=4)$ using the Shaffer-simulated method.

${ }^{\mathrm{x}} 20$ - to $25-\mathrm{cm}$ diameter whole loblolly pine trees harvested, chipped, and hammermilled to pass a $0.95-\mathrm{cm} \mathrm{screen} ; 1 \mathrm{~cm}=0.3937$ inch.

Therefore, greater substrate container capacity and lower substrate air space was expected for PB:PM and WPT:PM. High rooting percentages and subsequent root development was an indication that sufficient water content and adequate aeration was present in all substrates and maintained within the propagation system used for these experiments.

Disparities in root development among substrates are rarely attributed to differences in physical properties, unless extreme values are observed. Typically, low substrate air space $(<10 \%)$ and high substrate container capacity $(>60 \%)$ are considered undesirable for cutting propagation due to low oxygen content (Chen et al., 2003). Substrate air space above the recommended values, or a high proportion of coarse particles, may provide inadequate moisture or hinder contact between roots and substrate particles, but such conditions have not been widely reported for cutting propagation.

In the 2008 experiment, root development was superior in PB:PM compared with WPT:PM, despite similar substrate air space. In the 2009 experiment, root development was similar (for most species) in PB and WPT:PM corresponding to similarities in substrate air space. As a result, differences in root development cannot be attributed solely to substrate air space. Although substrate nutrient content is not a critical factor during root initiation, newly developed roots require an external source of nutrients for continued growth. Substrate cation exchange capacity refers to how effectively mineral nutrients (cations specifically) are bound to the substrate particles. Peatmoss and aged PB have a greater cation exchange capacity compared with wood-based substrates (Jackson et al., 2010; Raviv and Lieth, 2008). Nitrogen immobilization is another issue associated with wood-based substrates. Less nitrogen is available for plant absorption due to high microbial activity when comparing alternative substrates and PB with PM (Boyer et al., 2012).

In the 2009 experiment, substrate $\mathrm{pH}$ for all substrates ranged from 6.0 to 6.9 at $7 \mathrm{DAS}$ and 6.9 to 7.1 at 79 DAS (Table 10). Substrate $\mathrm{pH}$ was above the recommended range (5.5 to 6.5) for all substrates at 29 DAS and thereafter. An increase in substrate $\mathrm{pH}$ was observed between 7 and 29 DAS for all substrates, yet remained relatively stable within substrates from 29 to 79 DAS. Substrate EC was in an acceptable range for plug production $\left[0.5\right.$ to $1.0 \mathrm{dS} \cdot \mathrm{m}^{-1}$, (Cavins et al., 2000)] for all substrates except PB at 7 DAS, but was in the low range for all substrates at 29 DAS and thereafter. Substrate EC was similar among all substrates throughout the experiment. Changes in substrate $\mathrm{pH}$ and EC within the first $29 \mathrm{~d}$ are likely due to the nutrient release rate of the controlled-release fertilizer (Merhaut et al., 2006).

During propagation, nutrients are more readily leached from the substrate due to high substrate porosity and frequent mist application rates (Santos et al., 2011). Although water and nutrient availability can be readily managed in wood-based substrates used for crop production, such issues are more difficult in a propagation environment. The combined effects of leaching, low cation exchange capacity, and reduced nitrogen availability most likely contributed to less vigorous root and shoot growth in WPT.

The authors demonstrated that a range of plant species can be propagated from stem cuttings in WPT substrates. Combinations of WPT and PM or other organic components with a high cation exchange capacity may be required for optimum root development in WPT substrates. A single, universal propagation substrate has not been developed due to the unique set of factors associated with species variation and individual cultural practices. Rooting success is ultimately determined by the combined effects of container size, mist application rate and frequency, and substrate. Development of guidelines for propagation in WPT substrates would benefit manufacturers and growers interested in alternatives to traditional substrates.

\section{Literature cited}

Boyer, C.R., G.B. Fain, C.H. Gilliam, T.V. Gallagher, H.A. Torbert, and J.L. Sibley. 2008. Clean chip residual: A substrate component for growing annuals. HortTechnology 18:423-432.

Boyer, C.R., H.A. Torbert, C.H. Gilliam, G.B. Fain, T.V. Gallagher, and J.L. Sibley. 2012. Nitrogen immobilization in plant growth substrates: Clean chip residual, pine bark and peatmoss. Intl. J. Agron. Vol. 2012, Article ID 978526. 13 Nov. 2013. <http://dx.doi.org/10.1155/ 2012/978528>

Cavins, T.J., B.E. Whipker, W.C. Fonteno, B. Harden, I. McCall, and J.L. Gibson. 2000. Monitoring and managing $\mathrm{pH}$ and EC using the pourthru extraction method. North Carolina Coop. Ext. Serv. Hort. Info. Lflt. 590.

Chen, J., D.B. McConnell, C.A. Robinson, R.D. Caldwell, and Y. Huang. 2003. Rooting foliage plant cuttings in compostformulated substrates. HortTechnology 13:110-114

Chong, C. 1999. Rooting of deciduous woody stem cuttings in peat- and perliteamended MSW compost media. Compost Sci. Util. 7:6-14.

Fain, G.B., C.H. Gilliam, J.L. Sibley, C.R. Boyer, and A.L. Witcher. 2008. WholeTree substrate and fertilizer rate in production 
of greenhouse-grown petunia (Petunia xhybrida Vilm.) and marigold (Tagetes patula L.). HortScience 43:700-705.

Fonteno, W.C., C.T. Harden, and J.P. Brewster. 1995. Procedures for determining physical properties of horticultural substrates using the NCSU porometer. Hort. Substrates Lab., North Carolina State Univ., Raleigh.

Harrison, D. 2011. One of its poorest peat harvest seasons. 13 Nov. 2013. <http://www.greenhousecanada.com/ content/view/2934/>.

Hartmann, H.T., D.E. Kester, F.T. Davies, and R.L. Geneve. 2002. Plant propagation: Principles and practices. 7 th ed. Pearson Education, Upper Saddle River, NJ.

Jackson, B.E., R.D. Wright, and M.M. Alley. 2009. Comparison of fertilizer nitrogen availability, nitrogen immobilization, substrate carbon dioxide efflux, and nutrient leaching in peat-lite, pine bark, and pine tree substrates. HortScience 44:781-790.

Jackson, B.E., R.D. Wright, and M.C. Barnes. 2010. Methods of constructing a pine tree substrate from various wood particle sizes, organic amendments, and sand for desired physical properties and plant growth. HortScience 45:103-112.
Jackson, B.E., R.D. Wright, J.F. Browder, J.R. Harris, and A.X. Niemiera. 2008. Effect of fertilizer rate on growth of azalea and holly in pine bark and pine tree substrates. HortScience 43:1561-1568.

Lu, W., J.L. Sibley, C.H. Gilliam, J.S Bannon, and Y. Zhang. 2006. Estimation of U.S. bark generation and implications for horticultural industries. J. Environ. Hort. 24:29-34.

Merhaut, D.J., E.K. Blythe, J.P. Newman, and J.P. Albano. 2006. Nutrient release from controlled-release fertilizers in acid substrate in a greenhouse environment: I. Leachate electrical conductivity, $\mathrm{pH}$, and nitrogen, phosphorus, and potassium concentrations. HortScience 41:780787.

Offord, C.A., S. Muir, and J.L. Tyler. 1998. Growth of selected Australian plants in soilless media using coir as a substitute for peat. Aust. J. Exp. Agr. 38:879887.

Owen, J.S. and J.E. Altland. 2008. Container height and douglas fir bark texture affect substrate physical properties. HortScience 43:505-508.

Raviv, M. and H. Lieth. 2008. Soilless culture: Theory and practice. 1st ed. Elsevier, Oxford, UK.

Robbins, J. A. and M.R. Evans. 2005. Greenhouse and nursery series: Growing media for container production in a greenhouse or nursery-Part I (Components and mixes). Arkansas Coop. Ext. Serv. Bul. No. FSA6097.

Santos, K.M., P.R. Fisher, T. Yeager, E.H. Simonne, H.S. Carter, and W.R. Argo. 2011. Timing of macronutrient supply during cutting propagation of Petunia. HortScience 46:475-480.

Shah, M., A.M. Khattak, and N. Amin. 2006. Effect of different growing media on the rooting of Ficus binnendijkii 'Amstel Queen' cuttings. J. Agr. Bioscience 1:15-17.

Threadgill, C.C., C.E. Whitcomb, and R. McNew. 1985. Effects of propagation container dimensions and media on the growth of 4 nursery crops. J. Environ. Hort. 3:126-131.

Wright, R.D. 1986. The pour-through nutrient extraction procedure. HortScience 21:227-229.

Wright, R.D. and J.F. Browder. 2005. Chipped pine logs: A potential substrate for greenhouse and nursery crops. HortScience 40:1513-1515.

Wright, R.D., B.E. Jackson, J.F. Browder, and J.G. Latimer. 2008. Growth of chrysanthemum in a pine tree substrate requires additional fertilizer. HortTechnology 18:111-115. 